\title{
Insertion of an intrauterine catheter for post-cervical artificial insemination in gilts: a case report
}

\section{Introdução do cateter intrauterino para inseminação artificial pós- cervical em leitoas: um relato de caso}

\author{
Rafael da Rosa Ulguim ${ }^{1 *}$; Carine Mirela Vier²; Felipe Basquera Betiolo ${ }^{3}$; \\ Pedro Ernesto Sbardella ${ }^{4}$; Mari Lourdes Bernardi'; Ivo Wentz ${ }^{1}$; \\ Ana Paula Mellagi ${ }^{1}$; Fernando Pandolfo Bortolozzo ${ }^{1}$
}

\begin{abstract}
The aim of this case report was to characterize the insertion of an intrauterine catheter (IC) in gilts to perform post-cervical artificial insemination (PCAI). Attempts to insert ICs through the cervixes of gilts were performed using either a standard sow foam tip catheter (SFC; $n=25)$ or a standard gilt foam tip catheter (GFC; $n=25)$. The percentage of passage, depth and degree of difficulty for insertion were evaluated. The average depth of IC insertion was $10.1 \pm 1.3 \mathrm{~cm}$ for SFC and $10.0 \pm 1.2 \mathrm{~cm}$ for GFC. For both catheters, insertion depths of greater than $10 \mathrm{~cm}$ were achieved in the first insemination in $44 \%$ of gilts. Insertion depths of greater than $6 \mathrm{~cm}$ were observed in $72 \%$ and $60 \%$ of attempts using SFC and GFC, respectively. A high level of difficulty for IC insertion was observed, mainly while using GFC. In conclusion, the routine application of PCAI in gilts on swine farms remains limited by the low success rate for intrauterine catheter insertion. In further studies, we suggest evaluating reproductive performance using low insertion depths for PCAI in gilts, and assessing the use of sow foam tip catheter as a guide to introduce the IC.
\end{abstract}

Key words: Artificial insemination. Foam tip catheter. Intrauterine. Nulliparous sows.

\section{Resumo}

O objetivo deste relato de caso foi caracterizar a inserção de um cateter intrauterino (IC) em leitoas para realização da inseminação pós-cervical (PCAI). Tentativas de inserir o IC através da cérvix em leitoas foram realizadas usando um cateter de ponta de espuma padrão utilizado para porcas (SFC; $\mathrm{n}=25$ ) e um cateter de ponta de espuma padrão utilizado para leitoas (GFC; $n=25)$. O percentual de passagem, profundidade e grau de dificuldade para a inserção do IC através da cérvix foram avaliados. A profundidade média de inserção do IC foi $10,1 \pm 1,3 \mathrm{~cm}$ para SFC e $10,0 \pm 1,2 \mathrm{~cm}$ para GFC. Para ambos cateteres, profundidades maiores que $10 \mathrm{~cm}$ para a inserção do IC na primeira inseminação foram possíveis em $44 \%$ das leitoas. Inserções maiores que $6 \mathrm{~cm}$ foram observadas em $72 \%$ e $60 \%$ das tentativas utilizando SFC e GFC, respectivamente. Alto nível de dificuldade para a inserção do IC foi observada, principalmente para GFC. A aplicação da PCAI em leitoas, na rotina prática em granjas

1 Profs., Setor de Suínos, Universidade Federal do Rio Grande do Sul, UFRGS, Porto Alegre, RS, Brasil. E-mail: rafael.ulguim@ ufrgs.br; ivowentz@gmail.com; ana.mellagi@ufrgs.br; mari.bernardi@ufrgs.br; fpbortol@ufrgs.br

2 Discente de Mestrado, Kansas State University, KSU, Manhattan, KS, Estados Unidos. E-mail: carinevier@ksu.edu

3 Discente de Graduação, Universidade Federal do Rio Grande do Sul, UFRGS, Porto Alegre, RS, Brasil. E-mail: felipe.betiolo@, gmail.com

4 Médico Veterinário, Elanco do Brasil, Elanco, São Paulo, SP, Brasil. E-mail: sbardella_pedro_ernesto@elanco.com

* Author for correspondence 
de suínos, permanece limitada pela baixa taxa de sucesso para a inserção do IC. Em estudos futuros, sugerimos o uso de menor profundidade de inserção para realizar a PCAI em leitoas e o uso de cateteres de porcas como guia para introduzir o cateter intrauterino.

Palavras-chave: Inseminação artificial. Cateter de ponta de espuma. Intrauterina. Porcas nulíparas.

\section{Introduction}

Post-cervical artificial insemination (PCAI) allows a reduced number of sperm cells to be used per sow inseminated, due to the uterine semen deposition. For this purpose, it is necessary to use a catheter and an intrauterine catheter (IC) to ensure the deposition of semen directly beyond the cervix (WATSON; BEHAN, 2002). The success rate of IC insertion through the cervix in multiparous sows is greater than $90 \%$ (BENNEMANN et al., 2004; SERRET et al., 2005; WATSON; BEHAN, 2002). Therefore, PCAI has been widely used to optimize labor of sows and enable the use of high genetic index boars. However, the use of PCAI is not recommended in gilts (VAZQUEZ et al., 2003) because the small size of the reproductive tract makes IC insertion difficult. Few reports are available regarding the success rate of IC insertion through the cervix in gilts. For these reasons, semen processing and artificial insemination of gilts need a specific methodology. Therefore, the difficulties associated with PCAI in gilts limits the potential of use of artificial insemination within the swine industry. Recently, a low success rate for PCAI in gilts using different sized catheters and strategies to reduce cervical contractions has been reported (HERNANDEZ-CARAVACA et al., 2017). However, as is typically the case for studies evaluating PCAI, information about the depth and level of difficulty of IC insertion are typically not reported. These aspects are important considerations to reduce the difficulty of IC insertion through the cervix. Although gilts represent approximately $20 \%$ of the breeding group, data regarding the IC insertion in gilts is lacking. Therefore, the objective of this study was to quantify the success rate and IC insertion depth of PCAI in gilts, to verify whether the technique is feasible to be used in these animals.

\section{Case Report}

The study was conducted on a sow farm in the South of Brazil. A total of 50 gilts (Agroceres PIC $1050^{\circledR}$, Patos de Minas, MG, Brazil) were randomly selected in their second estrus (weight $\sim 150 \mathrm{~kg}$ ) to evaluate IC insertion under field conditions. Attempts to insert the IC using an intrauterine polypropylene catheter (Magaplus $\mathrm{S}^{\circledR}$, Magapor, Zaragoza, Spain) with a diameter of $0.35 \mathrm{~cm}$ and length of $75 \mathrm{~cm}$ were evaluated. Two distinct groups of gilts were submitted to IC insertion using different foam-tip catheters as a guide. Estrus detection was carried out once a day and attempts of IC insertion were performed in the absence of a teaser boar.

The depth of IC insertion through the cervix was measured after removal of catheters from the reproductive tract, indicated by the distance between the tip of the foam catheter and the tip of IC. Insertion depths were classified as either $>10 \mathrm{~cm}, 6-10 \mathrm{~cm}$ or $<6 \mathrm{~cm}$. The degree of difficulty of IC introduction was characterized as follows: unsuccessful insertion, considered an insertion $<6 \mathrm{~cm}$ (Level 0); absence of difficulty (Level 1); successful insertion on the first attempt with some difficulty (Level 2); and, successful insertion with high difficulty after more than one attempt (Level 3). The presence of blood in the catheters was registered as present or absent. Statistical analysis was performed using the Statistical Analysis System (SAS) 9.1 (SAS, 2005). The values are expressed as mean \pm standard error of the mean. The GLM procedure was used for the analysis of depth of insertion according to the level of difficulty. Frequency distributions were analyzed using Fisher's Exact test for depth of insertion and difficulty of insertion.

In the first group of gilts $(n=25)$, a standard sow foam tip catheter (SFC) was used (Ponta de 
Espuma Bretanha ${ }^{\circledR}$, Passo Fundo, Brazil). Attempts to insert the IC were performed only in the first day of estrus (estrus onset). On average, the depth of IC insertion was $10.1 \pm 1.3 \mathrm{~cm}(1.5-18.0 \mathrm{~cm})$ in this group of gilts. Introduction of the IC beyond 10 $\mathrm{cm}$ on the first day of estrus was possible in $44 \%$ of gilts (Figure 1). Insertions $>6 \mathrm{~cm}$ in the first insemination were $72 \%$ successful in this group. However, high difficulty (level 3) for insertion of the IC was observed in $50.0 \%$ of gilts (Table 1). Level 3 difficulty was therefore associated with a shorter depth of insertion of the IC compared with level 1 or 2 (Table 1 ).

Table 1. Frequency distribution of the difficulty level and depth of insertion $(\mathrm{cm})$ of the intrauterine catheter (IC) according to the type of catheter used as a guide for IC insertion in gilts in which an insertion of at least $6 \mathrm{~cm}$ was achieved at the first insemination.

\begin{tabular}{lcccccc}
\hline \multirow{2}{*}{ Difficulty level } & \multicolumn{2}{c}{ SFC } & & \multicolumn{2}{c}{ GFC } \\
\cline { 2 - 3 } \cline { 5 - 6 } \cline { 5 - 6 } \cline { 5 - 6 } & Frequency & Depth of insertion & & Frequency & Depth of insertion \\
\hline Level 1 & $33.3(6 / 18)$ & $15.9 \pm 1.5^{\mathrm{a}}$ & & $6.7(1 / 15)^{\mathrm{a}}$ & 18.0 \\
Level 2 & $16.7(3 / 18)$ & $15.9 \pm 2.1^{\mathrm{a}}$ & & $6.7(1 / 15)^{\mathrm{a}}$ & 17.5 \\
Level 3 & $50.0(9 / 18)$ & $10.4 \pm 1.2^{\mathrm{b}}$ & & $86.6(13 / 15)^{\mathrm{b}}$ & $13.3 \pm 1.1$ \\
\hline
\end{tabular}

Level 1: absence of difficulty; Level 2: successful insertion at the first attempt with some difficulty; Level 3: successful insertion with high difficulty after more than one attempt. SFC: use of sow foam-tip catheter; GFC: use of gilt foam-tip catheter. Insertion $<6 \mathrm{~cm}$ was considered unsuccessful (Level 0), which represented 7 gilts in SFC and 10 gilts in GFC.

${ }^{\mathrm{a}-\mathrm{b}}$ Differs significantly within the column $(\mathrm{P}<0.05)$.

Figure 1. Success rates of insertion of the intrauterine catheter at the first insemination of estrus using a sow (SFC) or gilt (GFC) foam tip catheter as a guide for insertion.

\section{SFC}

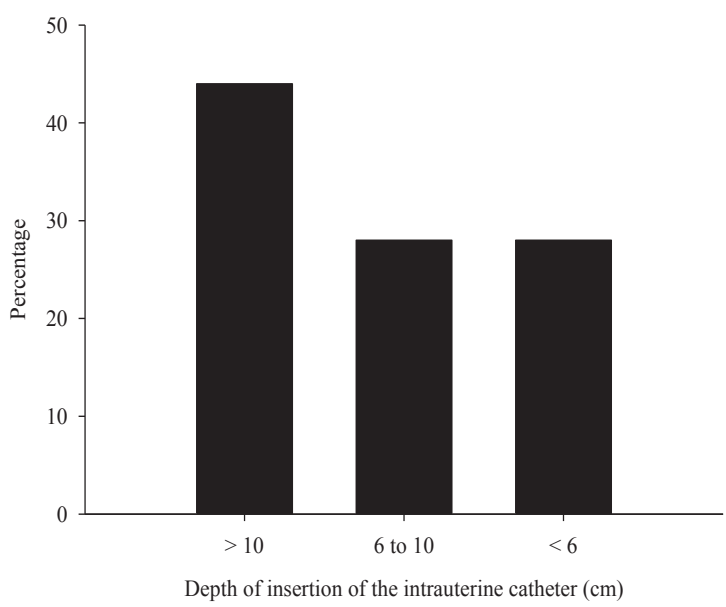

In the second group $(\mathrm{n}=25)$, gilts were inseminated using a standard gilt foam tip catheter (GFC; Ponta de Espuma Bretanha ${ }^{\circledR}$, Passo Fundo,
GFC

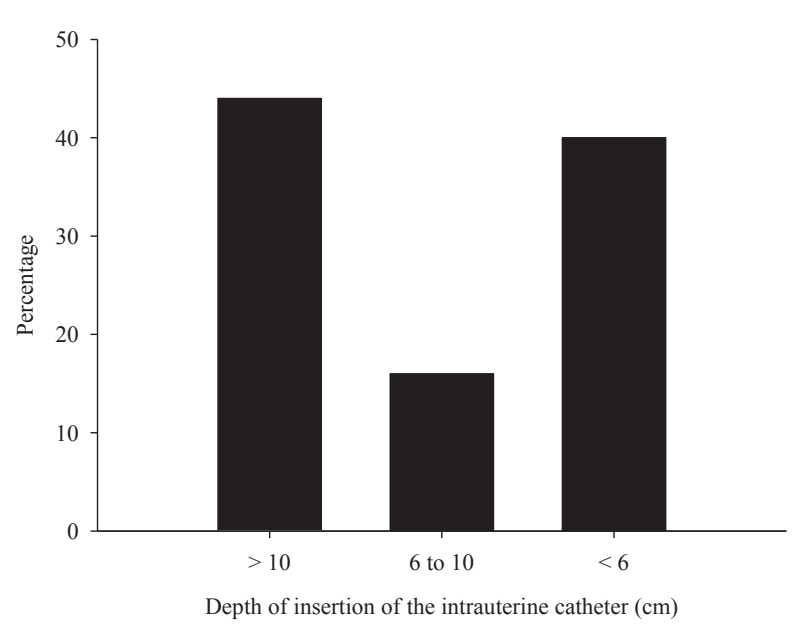

Brazil). Attempts at IC insertion were carried out at 0,24 and $48 \mathrm{~h}$ after estrus onset, while gilts remained in standing estrus. The mean depth of IC 
insertion was $10.0 \pm 1.2 \mathrm{~cm}(2.0-18.0 \mathrm{~cm})$. When insertion was attempted at $0 \mathrm{~h}$, the success rates of IC introduction beyond $10 \mathrm{~cm}$ or $>6 \mathrm{~cm}$ was $44 \%$ and $60 \%$, respectively (Figure 1). When the IC insertion was greater than $6 \mathrm{~cm}$ in the first insemination, insertion $>6 \mathrm{~cm}$ in the second insemination was possible in $75 \%$ of the gilts. For all inseminations during estrus using GFC, the success of insertion was $48 \%$ and $24 \%$ for depths $>6 \mathrm{~cm}$ and $10 \mathrm{~cm}$, respectively. Where insertion $>6 \mathrm{~cm}$ was achieved, high difficulty (level 3 ) was reported in $86.6 \%$ of gilts (Table 1). Differences in the depth of insertion of the IC in the first insemination were not noted using GFC, for any level of difficulty (Table 1). The presence of blood in the foam tip or catheter was observed in only one female of the GFC group and IC insertion had not been possible in this female.

\section{Discussion}

The low percentage of success (44\%) of insertion $<10 \mathrm{~cm}$ for both types of catheter agrees with the results of Hernandez-Caravaca et al. (2017) for IC insertion in gilts using specific catheters for multiparous sows $(19.6 \%)$ or gilts $(37 \%)$. In addition to the success rate for IC insertion, the depth and level of difficulty for IC insertion through the cervix were evaluated in this study as a new approach for the characterization of IC insertion in gilts. Overall, high levels of difficulty and low depths of IC insertion were observed. These results are important considering that few studies related to IC insertion in gilts are available, and enable us to suggest factors for consideration in further studies.

The cervixes of gilts have an average length of $12.0 \pm 2.1 \mathrm{~cm}$ (KAPELANSKI et al., 2013). The foam tip has a length of approximately $4 \mathrm{~cm}$ and is fixed in the first cervical folds, therefore, an 8 $\mathrm{cm}$ foam insertion would be sufficient to reach the uterine body. With this in mind, insertion of $>6 \mathrm{~cm}$ can be considered as sufficient for PCAI in gilts.
Differences among breeds may play an important role in the adoption of the PCAI technique under field conditions. As the GFC is thinner than the SFC it enables cervical fixation at a greater depth, and can therefore reduce the distance of IC insertion required for semen to reach the uterus. However, in the present study, similar percentages of success for insertions greater than $10 \mathrm{~cm}$ were observed using SFC and GFC in the first insemination. HernandezCaravaca et al. (2017) demonstrated higher rates of success of IC insertion when a standard catheter for gilts was used.

In the present study, when the insertion depth using the GFC catheter was greater than $6 \mathrm{~cm}$, the frequency of the passage of IC decreased and difficult increased. We consider that the reason for the overall increase in difficulty level was due to difficulty in handling the GFC as a guide for insertion of the IC due to poor cervical fixation. When IC insertion was difficult in the first insemination, greater difficulty was also experienced in following inseminations during the same estrus. This finding corroborates the results of Sbardella et al. (2013) for primiparous sows.

In practice, complete insertion of the IC may not be possible for a large percentage of gilts, and the use of this technique for all inseminations throughout the estrus (multiple inseminations) may also be limited.

\section{Conclusion}

The use of PCAI in gilts as a routine method in swine farms remains limited by the low success rate of insertion of the intrauterine catheter. In further studies, we suggest that the use of PCAI in gilts of genetic lines with larger body sizes should be evaluated. We also suggest evaluation of the reproductive performance for PCAI in gilts using sow foam tip catheter and considering a lower depth for intrauterine catheter insertion. 


\section{Acknowledgements}

The authors would like to thank Capes and Agroceres PIC for their financial support. Appreciation is also expressed to Master Genética Animal for the use of animals and facilities.

\section{References}

BENNEMANN, P. E.; MILBRADT, E.; DIEHL, G. N.; WEBER, D.; SCHIMIDT, A. C. T.; BERNARDI, M. L.; WENTZ, I.; BORTOLOZZO, F. P. Reproductive performance of sows submitted to intrauterine insemination at different pre-ovulatory intervals. Animal Reproduction, Belo Horizonte, v. 1, n. 1, p. 106-110, 2004.

HERNANDEZ-CARAVACA, I.; LLAMAS-LÓPES, P. J.; IZQUIERDO-RICO, M. J.; SORIANO-ÚBEDA, C.; MATÁS, C.; GARDÓN, J. C.; GRACÍA-VÁSQUEZ, F. A. Optimization of post-cervical artificial insemination in gilts: effect of cervical relaxation procedures and catheter type. Theriogenology, Stoneham, v. 90, n. 1, p. 147-152, 2017.

KAPELANSKI, W.; JANKOWIAK, H.; BOCIAN, M.; GRAJEWSKA, S.; DYBALA, J.; ZMUDZINSKA, A. Morphometric characteristics of the reproductive system in polish large white and polish landrace gilts at $100 \mathrm{~kg}$ body weight. Annals of Animal Science, Balice, v. 13, n. 1, p. 45-53, 2013.
SBARDELLA, P. E.; ULGUIM, R. R.; FONTANA, D. L.; FERRARI, C. V.; BERNARDI, M. L.; WENTZ, I.; BORTOLOZZO, F. P. The post-cervical insemination does not impair the reproductive performance of primiparous sows. Reproduction in Domestic Animals, Berlin, v. 49, n. 1, p. 59-64, 2013.

SERRET, C. G.; ALVARENGA, M. V. F.; CÓRIA, A. L. P.; DIAS, C. P.; CORCINI, C. D.; CORRÊA, M. N.; DESCHAMPS, J. C.; BIANCHI, I.; LUCIA JÚNIOR, $\mathrm{T}$. Intrauterine artificial insemination of swine with different sperm concentrations, parities, and methods for prediction of ovulation. Animal Reproduction, Belo Horizonte, v. 2, n. 4, p. 250-256, 2005.

STATISTICAL ANALYSIS SYSTEM INSTITUTE SAS Institute: SAS User's guide. Release 9.1.3. Cary: SAS Institute, 2005.

VAZQUEZ, J. M.; MARTINEZ, E. A.; PARRILLA, I.; ROCA, J.; GIL, M. A.; VAZQUEZ, J. L. Birth of piglets after deep intrauterine insemination with flow cytometrically sorted boar spermatozoa. Theriogenology, Stoneham, v. 59, n. 7, p. 1605-1614, 2003.

WATSON, P. F.; BEHAN, J. R. Intrauterine insemination of sows with reduced sperm numbers: results of a commercially based field trial. Theriogenology, Stoneham, v. 57, n. 6, p. 1683-1693, 2002. 
